\title{
The Melancholy of a Political Documentarist
}

\section{Michael Chanan}

Exploring the conditions and desire for political documentary at the present conjuncture, drawing on the author's experience as a London-based freelance documentarist since the 1970s and especially, since the turn of the millennium, making documentaries from a base within academia.

\section{Imagining the future}

We have arrived at a situation imagined by the revolutionary Cuban filmmaker Julio García Espinosa back in 1969 in his polemical essay 'For an imperfect cinema' (Por un cine imperfecto), when he asked:

What happens if the future holds the universalization of university education, if economic and social development reduce the hours in the work day, if the evolution of film technology (there are already signs in evidence) makes it possible that this technology ceases being the privilege of a small few? What happens if the development of videotape solves the problem of inevitably limited laboratory capacity, if television systems with their potential for screening independently of the central studio renders the endless construction of movie theaters superfluous? (Espinosa 1983, 28)

Everything he envisaged here - except the reduction in working hours - has effectively taken place, and much more. If the explosive development of digital videography is one of the definitive aspects of the new media landscape of twenty-first century mass culture (albeit unevenly distributed, leaving many places not yet fully inserted into this global communications heaven) then it takes us back to old dreams about the democratization of the media, like Dziga Vertov in Soviet Russia in the 1920s conceiving the idea of a network of local cine-amateurs providing a continuous flow of newsreel footage. Or Bertolt Brecht, writing about radio in 1932 as a medium with the inherent capacity to become 'the finest possible communications apparatus in public life', a vast system of channels of communication, or it could be if it were allowed to transmit as well as receive, 'to let the listener speak as well as hear... to bring him into a network instead of isolating him' (Brecht 2000, 42). These, said Brecht, are utopian ideas, but in that case, ask yourself why they're utopian.

However, now that we have this utopian communications apparatus, which does everything Vertov, Brecht and Espinosa imagined and more, we are bound to ask what kind of Pandora's box it has turned out to be. It is not the promised land its early adopters believed but more like a black hole which devours everything and spits out random scraps and crumbs (or maybe not so random - it depends on the algorithm). If digital video has made the creation of this stuff easy and cheap (discounting the time spent making it, a question I'll come back to), the bulk of it consists in trivia and trifles, and the first problem for left oppositional documentary is its submergence within this overwhelming flood of streaming video. Here it has to contend with various forms of disinformation, and with the attention deficit that the social media trade on, which induces brevity, simplification, sloganizing and 
the floating signifiers known as memes; nor is there any proven formula for what makes a video go viral, which is anyway an elastic concept. On the other hand, the popular take-up of desktop video has unleashed a huge amount of often playful and anarchic creativity, and activist video at its best can sometimes seem like a high-tech reinvention of the communist agit-prop of earlier times, at any rate, in aesthetic terms: the politics of post-communism tell a different story, in which, as Fredric Jameson put it, it has become easier to imagine the end of the world than the end of capitalism (Jameson 2003, 76). Meanwhile, video activism takes advantage of the internet for fundraising, dissemination, organising screenings and campaigning, but unfortunately, this is a poor basis for making a living.

As for myself, this quickly brings up another question, of a self-reflexive order. Where does a practitioner of independent left political documentary, belonging to a generation that found its politics on the streets in 1968, who now has a part-time day job in academia and an account on Vimeo, fit in to it all?

\section{Left-wing melancholy}

The story I have to tell (in formal terms: the narrative framework for this piece of autoethnography) begins in the early 1970s, in London (where I still live), when after a couple of amateur efforts and armed with a degree in philosophy, I started getting work as a freelance director, including a couple of documentaries on music for the BBC. This provided an early introduction to both the inside of public service television and the precarious nature of freelance employment. I then got a job teaching in a film school (and felt like an unemployed filmmaker employed to teach other people how to become unemployed filmmakers) until new opportunities arose with the creation of Channel 4 at the start of the 1980s, which provided slots for a whole new generation of critical independent filmmakers; when the channel's policy changed around the end of the decade, I returned to teaching. In parallel with this trajectory I also learnt of political film cultures in other parts of the world that metropolitan culture rendered peripheral, a process that began when I worked in the Chile Solidarity Campaign and was called on to curate a season of Chilean films focussed on the urgent cinema of Popular Unity (Chanan 1976). Visiting Havana for the first time in 1979 to begin research on Cuban revolutionary cinema opened a perspective on the wealth of left political cinema throughout Latin America, where I shot several films in the 80s, including an investigation of the New Cinema of Latin America for Channel 4 which took me to seven different countries (Chanan 1983).

The 70s inherited a strong sense of militant left documentary from the previous decade and the short but exhilarating moment of radical desire identified with 1968. It wouldn't last, because the politics involved didn't last. Latin America became polarized. While revolutionary forces triumphed in Nicaragua in 1979, elsewhere revolutionary movements were destroyed by brutal military regimes which, like that of Pinochet in Chile, adopted the neoliberal economic policies emanating from Chicago; radical cinema became 
impossible, the filmmakers driven into exile or disappeared. By the early 80 s, although oppositional filmmaking remained possible in the metropolis, both the UK and the USA were captured by the same neoliberalism, soon to be adopted across Europe, and the left was forced onto the defensive; except for a brief period of optimism in the middle of the decade, when Mikhail Gorbachev took power in the Soviet Union and under the watchwords 'glasnost' and 'perestroika', put radical reform of communism on the agenda. But it turned out to be too late. With the collapse of communist regimes across Eastern Europe, the fall of the Berlin Wall, finally the disappearance of the Soviet Union itself and thus the end of the Cold War, everything changed. No-one, neither left nor right, had expected such a momentous event, because both believed equally - in their different ways - in the irreversibility of history. The right, caught unawares, felt vindicated and became intolerably triumphalist. The socialist left, weakened by internal rifts and already demoralized by the assaults of neoliberalism, was cast from confusion into depression. More than depression. Melancholia.

The idea of left-wing melancholy isn't new, and has antecedents in both Sigmund Freud and Walter Benjamin. While Freud (1917) was thinking in terms of individual pathological dispositions when he described the difference between mourning and melancholia, when Benjamin spoke of 'left-wing melancholy' in early 1930s Germany, he used the term to indicate a mood he found in certain popular left-wing poetry and summed up as the attitude to which, though socialism remains ensconced as an ideal, 'there is no longer...any corresponding political action' (Benjamin 1999, 425). The result of the disconnect is nostalgia and even sentimentality. But this is only an example, not a theory, and the melancholy of the left in the twenty-first century has a different character. In the old days, it was said that the future was either socialism or barbarism. In the present day, more than ten years after capitalism's near-death experience in 2008, the brute imposition of austerity and the collapse of social democratic politics in Europe; after the defeats of the Arab Spring; and with the ongoing war in Syria, continuing strife in Africa, the refugee crisis and the rise of neofascistoid populism on both sides of the Atlantic, not to mention gathering environmental ruination - after all this and more, the great fear is that the manifest order of the day is indeed barbarism. And it isn't coming, it's already here. I know this feeling. Many people feel it; and I know they do, because they say so. It also crosses generations. The youth whom we try to teach, who are glued to social media but periodically rouse themselves to protest, are often equally disenchanted, not just because of their precarious and debt-riven immediate prospects but also in the face of the horrible future now facing them which will be wrought by the ecological crisis of the Anthropocene. None of which means that melancholia should be considered a disincentive to political action, only that politics urgently needs recalibrating.

According to Freud, melancholia is closely related to mourning, from which it borrows some of its features. Both are responses to the loss of a love object-generally a person, but also what Freud called an 'abstraction': an ideal such as one's country, or a sense of liberty, for example. But where mourning, he averred, is a healthy and normal process to be worked through, melancholy is an abnormal and persistent state in which the ego, which needs to let go of the lost object, nevertheless holds on to it, thereby blocking the work of 
mourning. The debilitating result of melancholia according to Freud is that the ego is split, and generates fears, anxieties, denial and self-reproach, a condition which can be traced, he says, to 'what is commonly called "conscience"'. According to Enzo Traverso in a recent book on the subject (2016), it is this sense of conscience that turns left-wing melancholia into a positive force. The history of socialism is a history of noble defeats and revolutions successful and unsuccessful. The tradition of commemorating the historical defeats of the struggle for socialism - 1848, the Paris Commune, the Spartacist Revolution, etc. - is more than mourning for fallen comrades but a reminder and celebration of the desire and hope for a better future which motivated them; it is not about a lost past but a future postponed.

But after the collapse of the Soviet Union, which in the end proved incapable of reforming itself from within, does this work anymore? Is there anywhere where it's possible to envisage the revolutionary aspiration of seizing power and overthrowing the capitalist state actually coming about? If this is what communism means, hasn't it been relegated to the rubble piling up unseen in front of the angel in Klee's painting 'Angelus Novus' which Benjamin described in his 'Theses on History'?

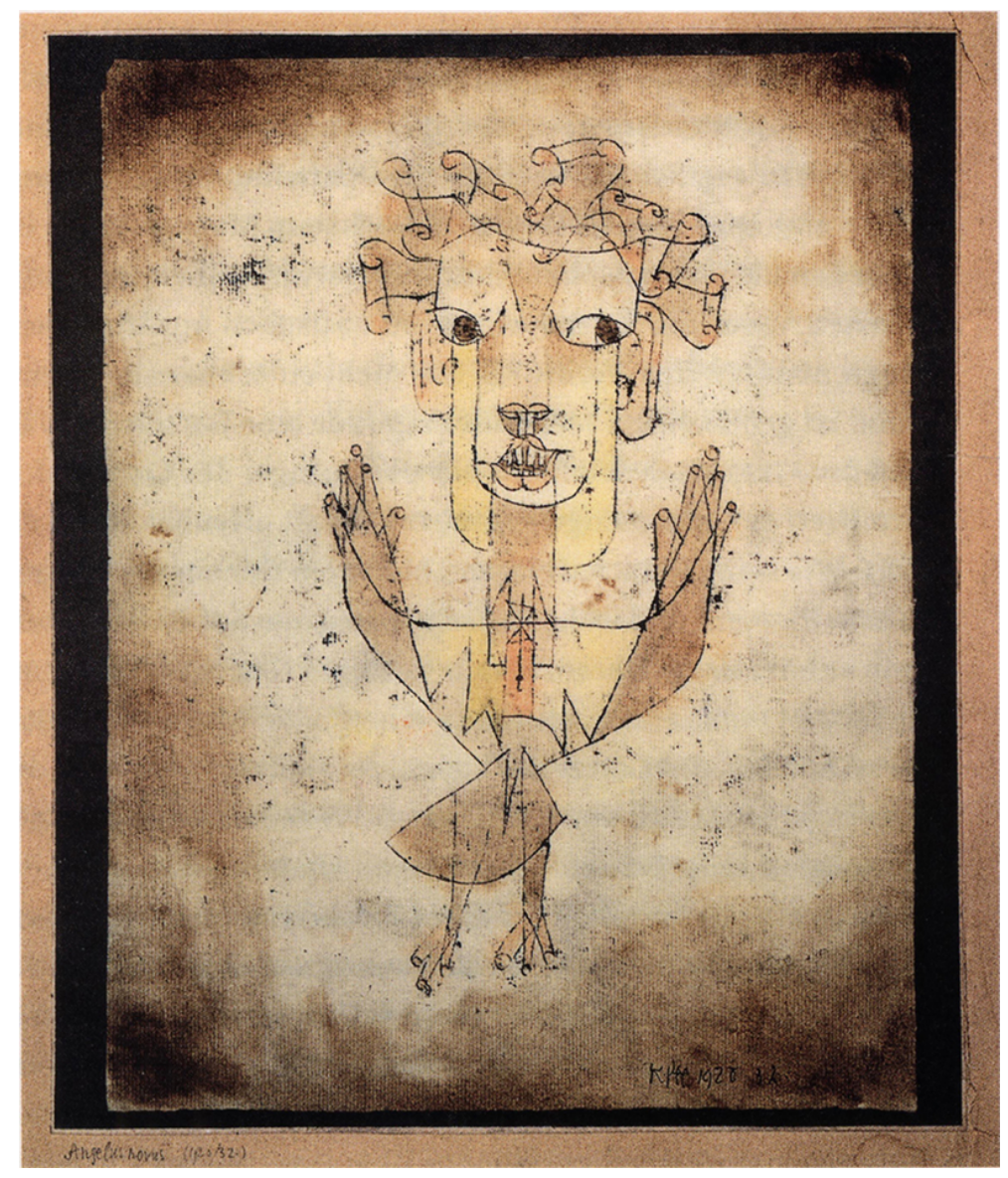

Paul Klee, 'Angelus Novus'

The angel is facing backwards, '[b]ut a storm is blowing from Paradise, it has caught itself up in his wings and is so strong that the Angel can no longer close them. The storm drives him irresistibly into the future, to which his back is turned, while the rubble-heap before him grows sky-high.' (Benjamin 1969, 257-8) Now communism is over and done with, it lies at the top of the unseen pile, a failed experiment even in states which are nominally still 
communist, a finished experience - and an irreparable loss. In this purview, the downfall of the communist form of socialism - we called it 'actually existing socialism' in order to signal its deformations - seemed to exhaust the historical trajectory of the socialist project more broadly, leaving just a few remnants behind. The left was robbed of its vocabulary and its vision. The utopian imagination was paralyzed and displaced by proliferating dystopian visions. The class struggle ceased to be a unifying concept and radical politics broke up into sectional struggles over race, gender, sexuality, in short, identity politics, all of which became subject matter for documentary. No new utopia has yet emerged, only the conviction, nurtured by the anti-globalization and environmentalist movements, that another world is possible - and indeed, necessary.

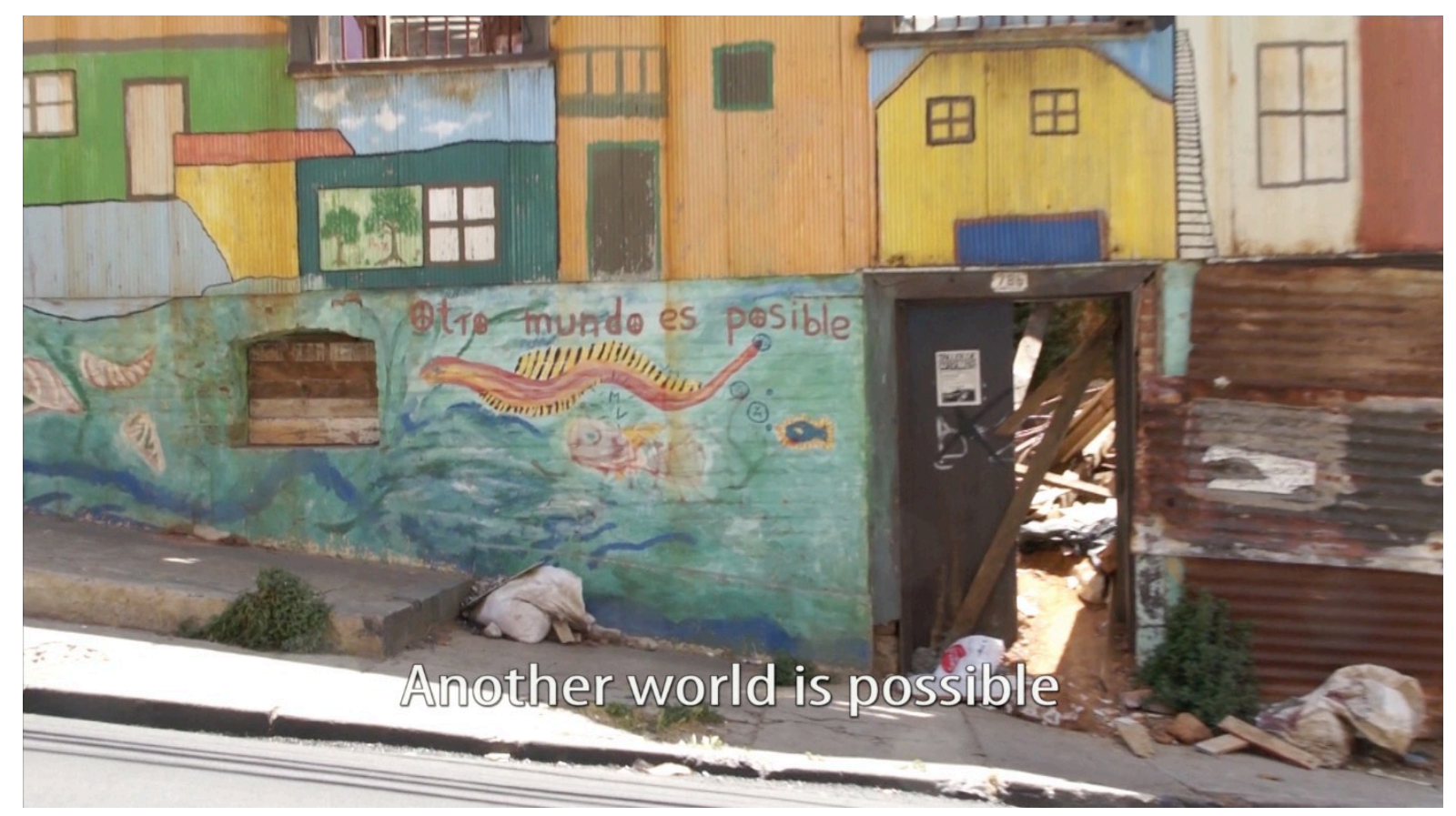

'Three Short Films About Chile'

Just as Gramsci averred, the crisis consists precisely in the fact that the old is dying and the new cannot be born, giving rise to a variety of morbid symtoms. The only thing we can say for sure is that new forms of political work are gestating beyond the orbit of institutional politics, laying down a challenge to the democratic deficit of the neoliberal state. A new grassroots politics is emerging in the social movements and jostling for position, and this is happening in different places around the globe. Each country and each struggle faces its own complications but the social movements transcend borders (a process aided by the internet) and often take on international dimensions. In 2015, while shooting Money Puzzles, I filmed an international gathering in Brussels held under the banner of the CADTM (Committee for the Abolition of Illegitimate Debt), a network with members in Europe and Latin America, Africa and Asia, which advocates citizen audits to expose illegitimate and odious public debt. A few weeks later I filmed debt activists in Spain who had designed a web tool to enable people to track the budgets of their local authorities and uncover shady practices and corruption, which was being used by citizen groups in a whole number of countries in Europe and Latin America. But if this could be seen as a practical example of 
'think global, act local', then at the level of the symbolic representation on the screen, documentary can do the same: portray in the same moment both what is particular to local struggles and simultaneously universal in its implications. Why? Precisely because globalization also works at both levels simultaneously (and various intermediary levels too). But also because this is what documentary does: it works in a double register, where the universal takes the form of the particular and the particular is liable to be read as a universal. In this way, even if we lack the critical acumen to see much beyond our noses, our cameras can testify to the activity of the social movements, their reasons and the critique they level against the ruling order. In short, this territory of anti-capitalist critique and mobilization is where I believe that left political documentary should now stake its claim, not just by representing collective action but as a form of activism in and of itself, and to borrow a phrase from the late Chuck Kleinhans (2018), 'adding to the visual imagination of political understanding'.

\section{Means of Production}

When I ask myself how I/we got here, my inner marxist prompts me to think about material factors, and therefore to ask about documentary's means of production, which have a determinant effect on who gets to make films and where they get to be seen. This is a story of complete retooling, phase by phase, from $16 \mathrm{~mm}$ film to digital video. In the process, established production practices are refashioned, and when the internet arrives, the longstanding division of the film industry into production, distribution and exhibition begins to break down. Production is reconfigured by the lowered costs and ease of use of the new digital technologies; new sectors of production develop, and a new mix of professional, semiprofessional and non-professional filmmakers. Distribution is now networked and potentially global (although impeded by language barriers, and in places by state control) and the web succors new enterprises, both big and small, outside traditional film industry capital. Exhibition is still governed by the prestige of theatrical screening, for which film festivals offer a coveted gateway, but is otherwise replaced by domestic and mobile screens (with restricted sound quality), in which reception is atomized and distracted, although the web also affords opportunity for social interaction. Ironically, these factors are highly conducive to documentary, although at the same time, what counts as documentary is stretched by factors like the expansion of expressive means and the weakening of convention.

The principle modes of documentary (to borrow Bill Nichols' [2001] term) were forged in the age of $16 \mathrm{~mm}$. Nowadays? $16 \mathrm{~mm}$ has totally disappeared, replaced by digital video. There are no longer any $16 \mathrm{~mm}$ film labs. Almost anyone (at least in metropolitan countries) can own everything needed, quality depending on price, but even a smartphone gives universal access to the sphere of circulation in cyberspace. A large amount of intelligent independently made video is now available at a click or two, ranging from brief bursts of citizen journalism uploaded directly from people's phones, to short and even long-form documentaries, dispersed amidst the fluff and the dross. But if it's a rule of left political documentary that it isn't designed to make money, nevertheless it still has to be paid for, even 
if the labor is voluntary or under-costed. The internet has responded by effectively reinventing the centuries-old convention of publication by subscription, which is now called crowdfunding. It is also a deceptive affair. As my university colleague William Brown explains, it requires much time and effort, if not financial expenditure, to mount a campaign, with no guarantee of success. The number of unsuccessful campaigns on the leading crowdfunding platform is nearly double that of successful ones, which 'means it is likely that a large number of filmmakers will lose money not in making their films but in trying to raise the money to make [them]' (Brown 2018).

Commercial production continues the established practice of trading skills and services within a sector of small to medium facilities companies with their own specialized staff. These are well supplied by eager graduates from innumerable media courses which encourage them to think in the appropriate terms, teaching them how to market themselves and their transferable skills, brushing over the truth about unpaid internships and precarious labor. The world they enter is one of egotistical and uncritical individualism, instilled by the ideological effects of the neoliberal hegemony which at the same time generates huge anxieties and great disaffection. However, for the socially minded and politically discontented there's an alternative, another arena, not in cyberspace but IRL - 'in real life' which lies outside the market but within communities, and among the grassroots involved in the social movements. Here video functions as 'small media', which flourishes in the margins and the interstices of the communication society, in contradistinction to the big, centralized corporate media, with their vertical address to aggregate audiences of consumers. In the sphere of small media, the video activist engages in direct encounter with a quite different audience-in-waiting, not comprised of anonymous millions, but local audiences brought together in small groups by social and political engagement. This was already possible in the era of $16 \mathrm{~mm}$ (and goes back to the film club custom of the cine-debate), like the screenings organised by Chile Solidarity in the 1970s when a local branch found a venue with a $16 \mathrm{~mm}$ projector and one of us arrived with a film.

There is a forgotten history to this practice, which I documented in three different countries in the film I made for Channel 4 on the New Latin American Cinema in the early 1980s: a shanty-town screening of a Chilean film in Mexico, a mobile cinema unit in rural Nicaragua, and in Colombia, a community screening by Marta Rodríguez and Jorge Silva of their latest film in Bogotá. 
Melancholy of a Political Documentarist

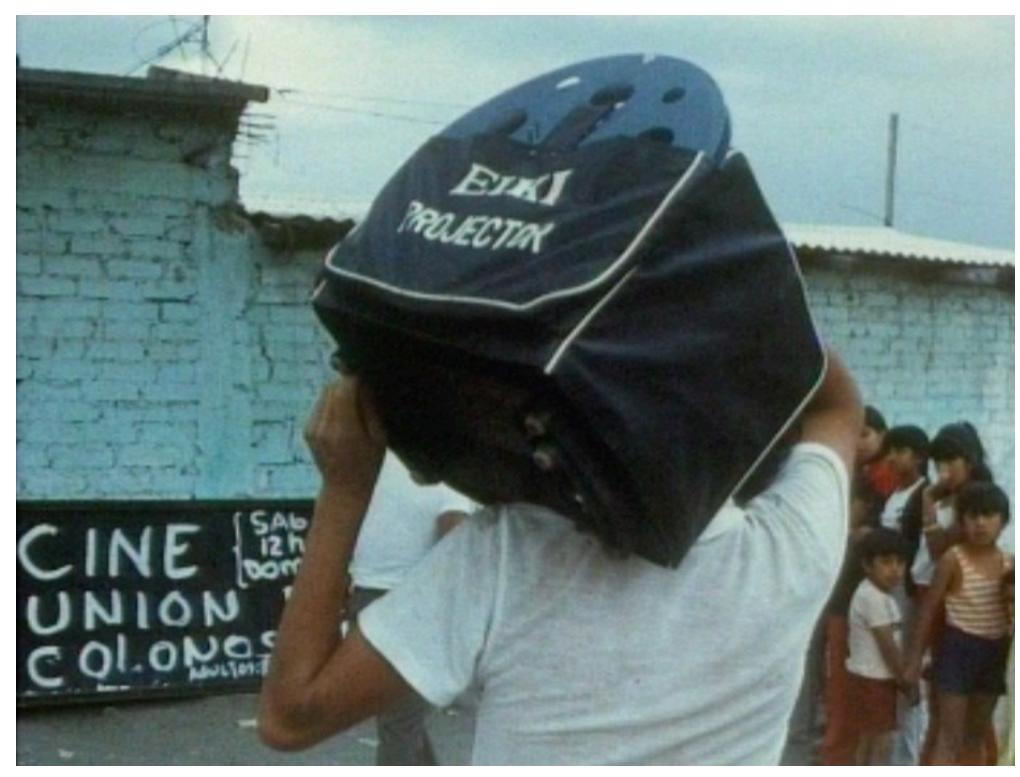

Screening in a Mexican shanty-town

Digital video greatly facilitates the revival of this practice, in which, for the filmmaker, the act of projection becomes the final stage of the production process instead of merely what comes after it. Nowadays portable video projectors can be set up and small-scale selforganised exhibition can take place anywhere - my own films have been screened in the upstairs room of a pub, a student occupation of a university building, even a tent at an activist summer camp. Audiences are small but I see this as a proper testing ground of left political film activity, where the film meets an audience outside the marketplace of commercial consumption and sparks discussion. The semi-anonymous forms of feedback provided by the internet are no substitute - but more of that below.

Video developed through several stages. First introduced into television studios during the 1950s, the first portable video system, Sony's substandard black-and-white open reel Portapak arrived in the late-1960s. The first and only time I got to use it was in 1973, to make a short video with kids from an inner city youth club. It was fun but disorderly, and as we had no access to editing equipment, it was never shown anywhere except the club. Nevertheless the experience was redolent of those utopian ideas I mentioned earlier, and brought a momentary sense of promise generated by the excited engagement of the kids. In retrospect, perhaps the most striking thing about it was how different it was from the discipline involved in the films I was making for television. The implication was that this was a new audiovisual medium sui generis, an idea which took hold among different groups of practitioners, from aesthetic avant-gardists to social activists, who naturally took the very materiality of the new medium in their own different directions.

By the start of the 80 s video had developed to the point where it had taken over television news production, where it was known as ENG (Electronic News Gathering). When we filmed the guerrilla movement in El Salvador in 1980, we were the only foreign crew in the country at the time shooting on film. El Salvador: Portrait of a Liberated Zone was made by just two of us (Peter Chappell on camera, myself on sound) on a commission from a West German television station (with another version made for solidarity screenings in the UK). We had a different brief from the news crews, however: not to film the war itself, but to show 
daily life in the zones of the country controlled by the FMLN (Farabundo Martí Liberation Front), without whom, in fact, the film would not have been made. Back in London, I offered the footage to the BBC current affairs program Panorama, who sent a researcher to see what I had, and then a producer came to see it, but in the end they didn't go for it. The producer was doubtful. He remarked that the questions I asked people were unusually sympathetic, instead of needling them as he would expect. An object lesson in the normative mindset of the mainstream. Working on the fringes of the mainstream media market only exposes you to the limitations of the institutional habitus embodied in the judgment of the gatekeepers.

The next time I worked on video was a few years later. In 1984, I was asked to produce a video for the Chile Solidarity Movement, for screening at the TUC and Labour Party conferences, on the first trade union delegation from Britain to visit Chile after the coup to investigate human rights abuses. The delegation brought back with them an anonymous videotape they'd been given to be incorporated into the video which we shot of their reportback meeting. The tape carried no title or credits, but it was not merely a series of useful shots; I well recall my amazement on first viewing it to find a fully edited reportage about the repression and the fight-back taking place on the streets. It was only on a visit to Chile many years later that I discovered its provenance: difficult to identify definitively, it had been made by one of the groups that started producing alternative newsreels in the early 80 s with support from foreign NGOs, disseminated domestically through the clandestine circulation which video replication made possible. (Liñero Arend 2010, 37-41, 59-64) In short, it was in the most inimical circumstances, under brutal military dictatorship, where every shot is filmed in conditions of risk, that video as a political tool came of age. It not only demonstrated its contribution to political struggle at home and solidarity work abroad. Applying the principles of anonymous collective production advocated by Solanas and Getino in their 1969 manifesto, 'Towards a Third Cinema' (Solanas and Getino, 1983), it also constituted anonymity as a political position, a form of political authorship.

\section{Mode of production}

The means of production have a determinate relationship to the mode of production, which in turn governs the forms of exploitation of labour power. We learned this from writers we read in the 70s who seem to have been forgotten. In this perspective, the old term freelance is a euphemism, a misnomer for a system of subcontracted labour. As Maurice Dobb (1963) pointed out, subcontracting, typical of the conditions of outwork and domestic labour in which capitalism developed, survived for much longer than was often recognized. And as Harry Braverman (1974) argued in his influential study of labour and monopoly capitalism, it prevailed because it was an effective means of control over the labour force wherever the techniques of scientific management like the Fordist production line are unavailable. Hollywood has been characterized as a Fordist film factory, but in fact film production is one of these problematic domains because the creative labor it calls upon proceeds at its own rhythms and is difficult, if not impossible, to quantify. A film crew at work is like an orchestra in which, at any given moment, some of the players are busy and others are silent, 
waiting for the moment when they make their particular contribution, which cannot be measured in terms of the number of notes they play. No matter. The film producer does their calculations on the basis of the number of minutes of screen-time shot per day.

Documentary occupies a peculiar position in this scheme. By definition, it is not a studio picture: it has to be shot wherever it has to be shot. It doesn't generally (or ideally) have actors and scripts and the crew is minimal. And it isn't backed by big finance (except for the newsreels, before television news killed them off). In short, documentary is what Joris Ivens somewhere described as a creative no-man's land, an interloper in the genre system. After acquiring a public service remit in the 1930s, when documentary entered television in the 1950s, it was captured within official codes of practice administered by a small army of program editors, channel controllers and station executives and intended to inscribe free speech and democratic values. Documentary was now divided into genres corresponding to the schedules, which also governed the permissibility of political discourse. The arts were relatively free as long as they didn't trespass too obviously. Current affairs was highly constrained. Freedom of speech in this regime is modulated by rules about balance and impartiality which are claimed as universal governing principles of public discourse about political truth under liberal democracy. However, these codes of practice are also a selfprotection racket, an expression of institutional paranoia. On close examination, the rules function with systemic bias to exclude unacceptable arguments and topics, and to expunge inconvenient contradictions.

Video, first analogue then digital, brings about changes which unsettle the established mode of production. It breaks down the traditional division of labour in the film crew and undermines the criteria of professionalism. Some of these trends were first manifested in the 1980s. A new class of user appeared, the 'semi-professional'; a new market category took shape - corporate or non-broadcast - ranging from medical teaching to corporate training to PR. Others, however, turned to NGOs with social concerns for funding or commissions. A large proportion of independent documentaries screened at several film festivals I've attended over recent years are funded this way. Here the habitus is much less normative than broadcasting, but still requires political discretion, leaving it an open question how far the films are conditioned by the expectations of the NGOs, who are not supposed to take political positions, whose politics, in other words, are those of human rights and humanitarianism. (I don't mean this dismissively; there are many excellent films in this mold.)

Digital video takes all this to a new level by encouraging solo videography. The equipment is nowadays cheap enough - less than a small car - that aficionados, students and simple amateurs can own all the necessary means of production in highly convenient form, compact enough to carry around. This is how I made Interrupted Memory in 2013, traveling around Argentina and Chile for three months, filming and editing on the road; funded by a couple of academic grants, and given that this didn't need to include labor costs, the budget was around $£ 15,000$. This is a film about politics and memory in two countries whose political trajectories were drastically interrupted by brutal military dictatorships in the 1970s and $80 \mathrm{~s}$, where asking about political memory inevitably touches an open social and political 
wound in the post-dictatorship; my intention was a film which positioned itself on the left by dint of its subject matter and its testimonies, but avoided sectarian positions and maintained a distance from official discourse on human rights in either country. Working this way offered several advantages. Not only did the mobility of solo videography allow me the freedom to film as I went along without a pre-established script, but I was able to show rough cuts of sequences and eventually nearly the whole film to collaborators before I left for home, and to take their feedback into account in the final edit.

As David MacDougall put it back in 2001: 'Now for the first time it has become possible to make a professional-looking film largely on your own, shooting it yourself and editing it in your home or office. Not everyone, obviously, is capable of doing so, but for those with the talent and tenacity, it can be done. This significantly challenges the power of the professional film-making establishment, with its customary financial backing, administrators, directors and specialist technicians' (MacDougall 2001). MacDougall described the benefits succinctly: filmmakers freed from the need to seek television funding, 'are also freed from many of the constraints that go with it: very large production budgets, oversized crews, broadcast deadlines, arbitrary film lengths..., the ministrations of commissioning editors, stylistic conventions (voice-over introductions, glossy series packaging, interviews, 'signposting', 'cracking the characters', horror vacui)'. It was around the same time that video filmmaking entered the purview of the academic funding agencies, anxious to demonstrate they were abreast of the wonders of digital media, and it thus became a legitimate form of research activity.

MacDougall maintains that solo filmmaking has special qualities. For one thing, the new smaller digital cameras (these are the ones I like to use) are regarded as amateur devices, associated in public places with tourism.

This perception carries over into the private realm, where someone with a video camera is viewed more as a person pursuing personal or local interests than wider institutional ones. As more people use cameras of their own, amateur cameras increasingly become associated with the idea of 'for us' rather than 'for them'. (2001 page? Or internet?) This changes the subject's relationship to the filmmaker. Says MacDougall,

I have found that it is possible to establish a quite different kind of rapport with my subjects when working alone - not always more trusting, but more relaxed, more flexible, more spontaneous and humorous, and sometimes more confiding. (2001)

This has been my experience also. I would add a technical detail: a significant element in this rapport is the camera's LCD screen, which obviates the need to hold the camera up to your face, and enables you to maintain eye contact while you film people talking to you. In filming Interrupted Memory this way, I was constantly amazed at what my subjects were telling me, and viewers have said that so are they. It helped to film people in a quiet and intimate setting, but what I've found, for example filming the anti-austerity movement in the UK in the winter of 2010-11, or in Greece and Spain in 2015, is that a measure of rapport is also characteristic in spaces of struggle (even when filming with two cameras) on condition that the camera is not identified as an agent of the big media. Where collectivity takes up residence, protestors 
hardly worry about their image being captured by a camera that they regard as one of their own. Indeed, they are likely to see their involvement as an extension of their own political objectives. Sometimes, for example at a protest against library closures in South London in 2011, people will invite the camera to let them speak their piece. ${ }^{1}$ They want to be represented, or rather, to represent themselves through you. In short, the collectivity brings about a potential space of disalienation in the relationship between the subject and the videographer, who is not then objectifying as much sharing an experience, an event, an attitude - and a politics.

However, solo filmmaking involves a liability - working alone deprives you of the collaboration and collective creativity of the film crew. I therefore jumped at the opportunity when the prospect arose to invent a new form of collaboration to compensate for the solitude, by working with the sociologist George Steinmetz on a film about Detroit and the rise and fall of the automobile industry. In other words, an academic investigator who brings the initial expertise and knowledge of the subject, conducts the interviews, and shares the development and intellectual authorship of the film from conception to final cut - a way of working I have subsequently repeated with variations according to circumstances. Detroit: Ruin of a City (2005) is a thoroughly political film but not activist or militant, not directly linked to a political movement or group or advocating a political program. We decided early on not to encroach on the city's current politics, so as not to let attention be diverted from our main intention, namely, to see the Motor City as a case study in US capitalism, its methods and ideology, conflicts with labor, structural racism and social consequences. Wishing to avoid the monological discourse of an impersonal commentary, we filmed ourselves in conversation, driving around the city in a car, or watching archive footage on a viewing machine. In short, we devised a methodology which fitted the subject, the circumstances, and the resources corresponding to our academic status. Crucially the film made much use of the film archives, including films made by the Ford Motor Company and workers' movement films of the 1930s and later, most of them in the public domain - otherwise we wouldn't have been able to afford it. The budget came from the AHRB in the UK, and the ASA in the US, but it wasn't more than around $\$ 25 \mathrm{~K}$; once again, this is because our labor costs didn't have to be included. In short, a historical documentary virtually impossible to make for television because of its marxist terms of reference, and certainly not on such a small budget, which would occupy a representational space between the esoteric discourse of academia and the populist discourse of the big media. A report in the Detroit Free Press described it accurately enough as 'a critical examination of how Detroit has gone from one of the world's greatest industrial centers to a city increasingly known around the world - especially in academia - as perhaps the best case study of urban decline' (Youssef 2005). 


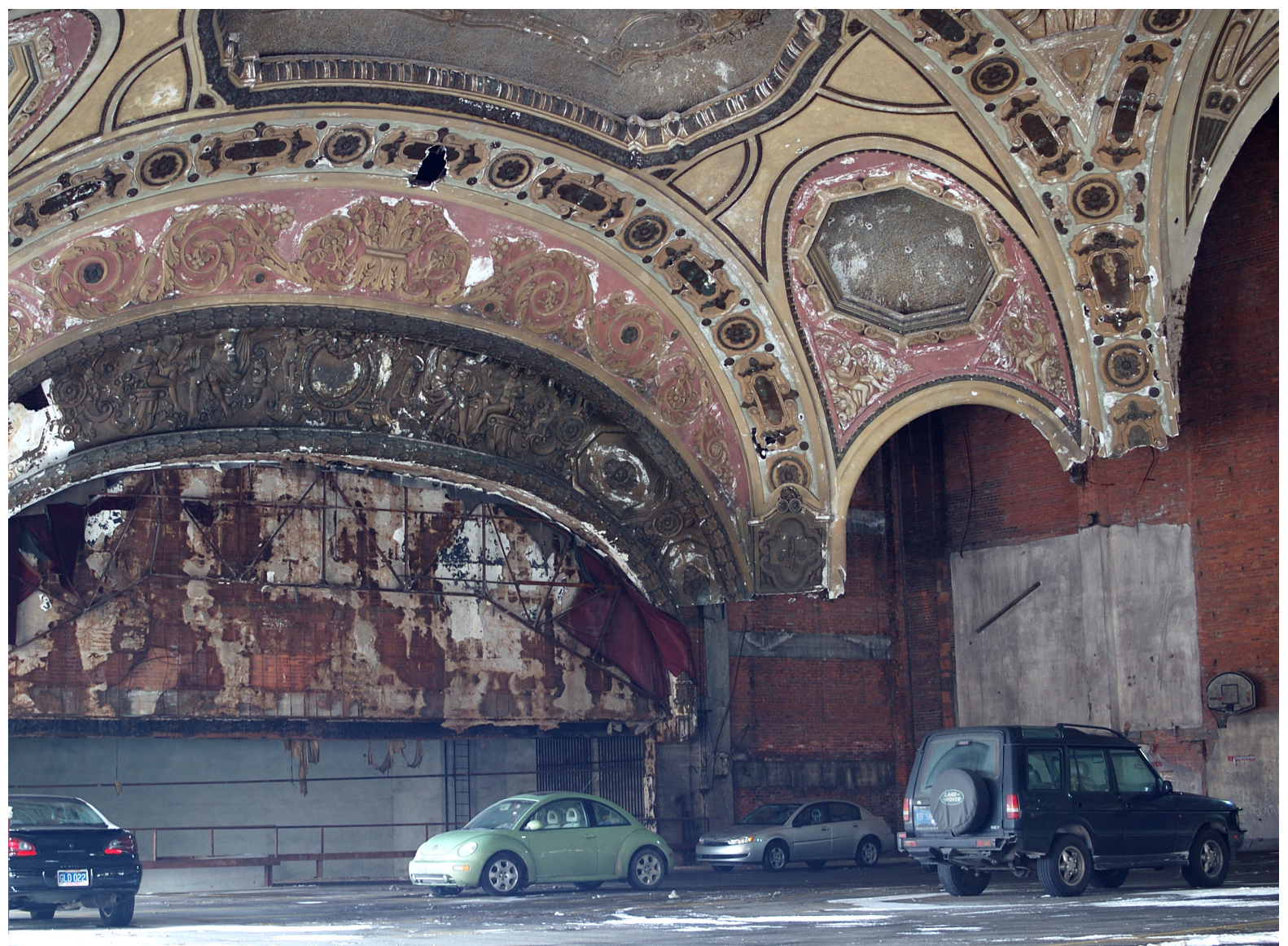

Detroit: Ruin of a City

The premiere of the film at the University of Michigan in nearby Ann Arbor became a vivid demonstration of the new conditions of reception being created by the internet. The title alone caused consternation. An announcement of the screening appeared on 'Detroit Yes', a website run by Lowell Boileau, one of the film's participants, who in the film takes us on a tour of what he calls 'the fabulous ruins of Detroit'. Within 48 hours there are two dozen responses, which mostly range from the sarcastic ('Well that's a fresh, exciting topic that's never been documented before ...') to the vitriolic ('I'm glad to see our tax dollars are being put to good use by the leftwing, America-hating professors at University of Michigan who cannot help but participate in what I predict will be a one-sided smear of the city they are all supposedly are so concerned about.'). Lowell e-mails us to explain that these come from what he calls Detroit 'nationalists'. Since no-one had yet seen the film, I wonder what drives these responses: if perhaps they arise from a fear of representation, of the exposure to ridicule of a dying object of attachment, or the public rehearsal of what had already become a 'bad object'. Nowadays such knee-jerk vilification would be called trolling, and the language would be much more aggressive. Back then, it simply served as good publicity, and a thousand people turned up for the screening in a lecture theatre seating 300. (Of course that was before people could reserve their seats on their cell phones.)

\section{Counter-narrative}

The changes described here are part of a bigger picture in which digital technology and neoliberal economics collide, and transform the character of both the culture industry and free 
cultural creation. The first, the digital, drives technical and aesthetic convergence, creates newly technified forms of collaboration, and offers novel possibilities to the cultural worker engaged in social networking. The second, the neoliberal economy, casualizes labor and inserts the individual into a new ecology of cultural production in which these same newly technified forms of collaboration are fragmented and employment is rendered precarious. The atomised cultural worker must learn to market themself, the social relations of collaborative networking are to be monetized, and the boundaries between aesthetic labor and business become ever more blurred.

Perhaps the possibility of political and oppositional filmmaking in these conditions depends on refusing the conditions of the market, which is only, with rare exceptions, bound to marginalize it in any case. In the first place, of course, because the mainstream media disparage anti-capitalist and socialist politics. But also because they don't know how to handle cultural products that don't present themselves as commodities competing for attention in the marketplace. While working under the aegis of academia means that you don't have a budget for marketing and publicity anyway, there are certain advantages to making films within the academy. Not merely for practical reasons, like not needing to pay lawyers and accountants, but crucially, by providing, under legal protection for academic freedom, a zone of intellectual and creative autonomy (at least until now, when pressures to conform to institutional research criteria are narrowing the funding options). For dissemination, you rely principally on the internet and social media. You need to reach beyond the academic networks and your initial group of activist supporters, but the law of the internet kicks in: the network you want to reach is always further away than the network you're able to reach beginning from the network you start off in. In short, the dispersed and fragmented character of the internet offers spaces for counter-discourses but only on condition of marginalization from the money-driven virtual mainstream.

Working independently, outside the market, restores some of the autonomy that Marx found in the freedom of aesthetic labor, on account of which he considered capitalism hostile to art (Chanan 2015). But today this leads to a new trap. Cultural production now falls into the category identified in the Italian autonomist concept of 'immaterial labor', which Michael Hardt and Antonio Negri define as 'labor that produces an immaterial good, such as a service, a cultural product, knowledge, or communication' (Hardt and Negri 2000, 290). Following Maurizio Lazzarato, it includes 'activity that produces the "cultural content" of the commodity... in other words, the kinds of activities involved in defining and fixing cultural and artistic standards, fashions, tastes, consumer norms, and more strategically, public opinion' (Lazzarato 1996, 132-46). Lazzarato's 'immaterial workers' are people who work in advertising, fashion, marketing, television and so forth, all of them producers of subjectivity. These activities belong to the culture industry as it came to be defined in the neoliberal economy, whose growth in recent decades corresponds to the intensified commodification of leisure which is integral to 'post-industrial' capitalism and follows from the convergence of the means of cultural production with information technology and the internet. But the internet has created a new parallel public sphere, where cultural functions are now also conducted by the audience - the fan base, the consumer, the targets of the culture industry - 
and not just those who work within it. The necessary skills are exercised by all sorts of people using the same digital tools, contributing content to the web - for free. In fact the distinctions are breaking down, as the most successful bloggers, for example, earn income from online advertising or commercial sponsorship, or join the gig economy which supplies online magazine publishers, some of which also produce their own videos.

This is what Brecht's utopia of communication looks like today. The web is largely channeled through the portals of corporations dedicated to an all-embracing consumerist ideology, for which participation is little more than a conditioned button-pushing reflex. Nonetheless, what digital convergence produces is not just the instant flow of free expression across borders but also a propensity for causing ideological upset by breaking down social and cultural barriers, and discovering new sociopolitical constituencies of every ideological inclination who often take to the streets where political battles involve bodies. There's a crucial rider, however. In succumbing to the invitation of the web, its openness, diversity and permissiveness, as cultural worker or as netizen, we provide the apparatus with content, the stuff that generates the clicks that drive the advertising that the corporations trade on, not to mention the metadata that intelligence agencies seek out, hackers steal, and data mining exploits. In other words, by becoming unpaid content providers, we allow ourselves to be commercialized and instrumentalized. And the converse: allowing ourselves to be translated into metadata, we become the product, the commodity, suitably re-packaged, that the whole business depends on. What happens to the idea of political documentary in this newly fluid and deceptive context?

There is no simple answer. Independent left political films nowadays come in all shapes and sizes, they are often highly inventive and in styles that are constantly evolving, so that any attempt at a taxonomy of political film genres is always provisional, never stable and quickly rendered out of date. All, however, are subject to an ecology of visibility which operates differentially through different types of screen. Documentaries made for television rarely make it into the cinema, but the big series get released as box sets, physical or digital. Documentaries intended for the cinema and DVD don't necessarily cross over to television but are likely to get streamed on the web. Social media comprise another ecology, largely separate and self-contained. The constraints of small screen viewing (with tinny sound) encourage simple signposting, the circulation of memes, short campaign publicity designed for best effect on a mobile phone. But in certain circumstances, like moments of mass protest or election campaigns, these can go viral and become effective instruments of mobilization.

We are left with what Jameson has called 'the dilemma of representation as such', because if you're aiming at capitalism and capitalism is a totality, then 'No-one has ever seen that totality, nor is capitalism ever visible as such, but only in its symptoms' (Jameson 2011, 4-6). Or as Brecht put it, in a remark cited by Benjamin, the simple reproduction of reality says very little about what it shows, and a photograph of, say, the Krupp works or AEG tells us almost nothing about these enterprises, because it cannot reveal the reification of human relations which is produced within them (Benjamin 1979, 255). For myself, these remarks struck home when I set out make a film about the City of London, the famous square mile 
synonymous with finance capital, which we called Secret City (2012) because it's a city within a city, governed by a private corporation dating back to medieval times, which operates under a cloak of ceremonial and concealment. You can film the space, the façades of its famous buildings, the crowd flowing over London Bridge, up the hill and down King William Street, but you cannot film the smell of money. The aesthetic premise of this film (and its sequel, Money Puzzles (2016)) is that economic reality is complex and dialectical in character, full of invisible forces acting and reacting, and this has to be inscribed in any attempt to represent how it works. Both films therefore employ techniques of montage, to which, as Susan Buck-Morss puts it, Benjamin afforded 'special, perhaps even total rights' as a progressive form because it 'interrupts the context into which it is inserted' and thus 'counteracts illusion' (Buck-Morss 1991, 67). Secret City incorporates footage from both the archive and the web. Money Puzzles presents a multitude of materials in a variety of ways, from simple illustration and quotation to ironic interruption and dialectical juxtaposition, in order to map the circularity and self-referentiality of the way the capitalist system is normally represented. Here too the academic filmmaker benefits, allowed to borrow material free of copyright for educational purposes, and thus to plunder the web for clips to deconstruct the confusing variance of imagery which surrounds us. This, however, is another factor keeping the film out of commercial distribution.

Secret City first saw the light of the projector with a screening at the House of Commons in 2012, invited by one its participants, the then back-bench Labour MP John McDonnell (now left-hand man to Jeremy Corbyn in the revived Labour Party). A sufficiently high-profile debut to result in its rapid take-up, with approaching 90 screenings across the UK over the following year. Audiences were largely comprised of sympathizers of the Occupy movement of autumn 2011, of all ages but mainly youthful, expressing a range of middle to hard left political sentiments, and belonging to three key and partly overlapping constituencies: academic audiences; political audiences; and general audiences, typically including, for example at London's Frontline Club, journalists and other professionals. Since the film told most people stuff they didn't know about the way the City of London is governed, but refrains from suggesting solutions in the style of numerous campaign films of recent years, the reaction in discussion typically moved from initial astonishment to wide ranging debate about financial capitalism and the democratic deficit of actually existing democracy (Chanan and Salter 2016). 


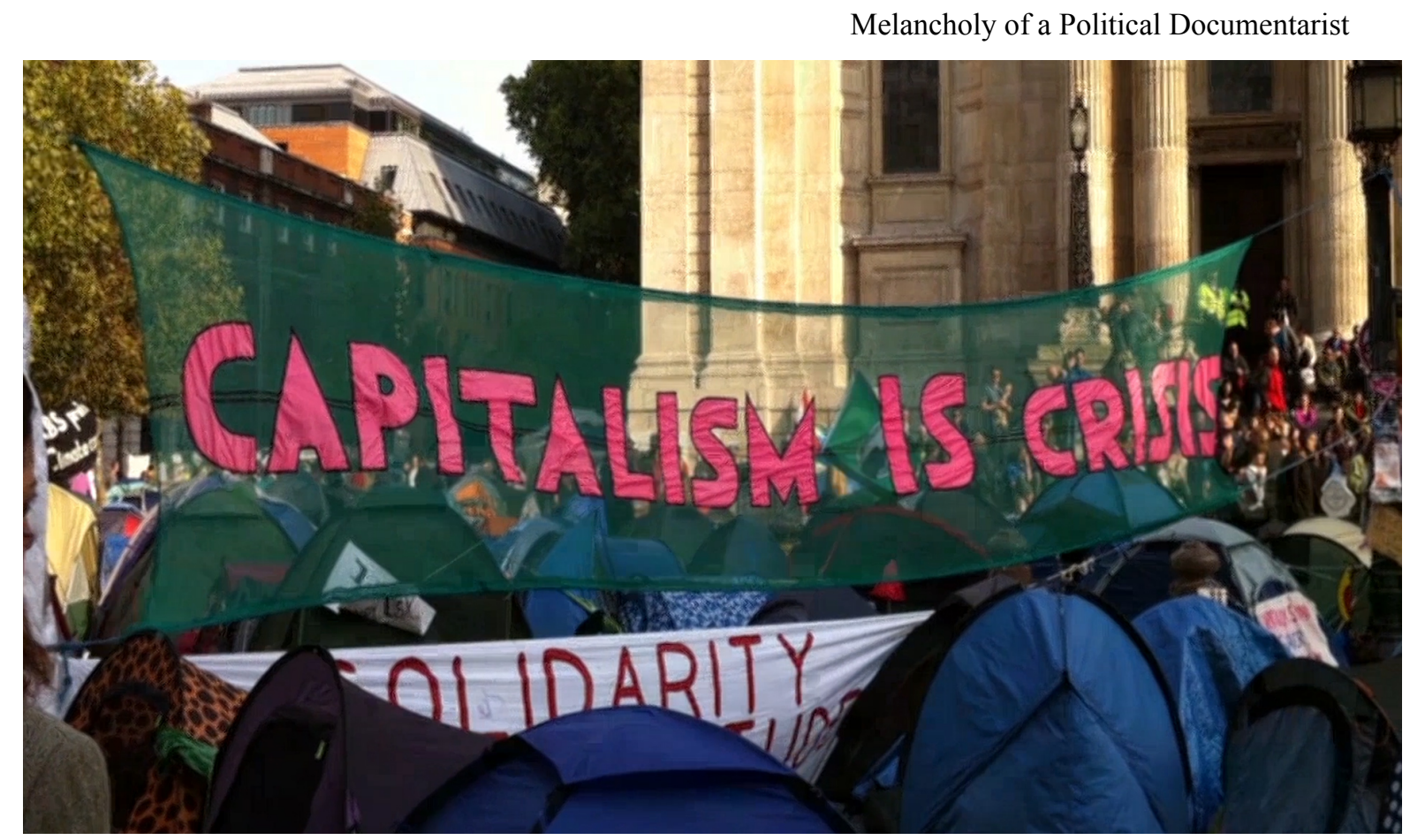

Secret City

Secret City garnered 166,000 hits on YouTube over the next five years, a significant number but still a tiny one in the grander scheme of things. Who does this serve? I recall a screening of the El Salvador film in Sheffield in the 1980s, when the local solidarity group invited a local radio reporter to come along and interview me. She asked me if the film wasn't just preaching to the converted and I found myself answering, 'Maybe, but even the converted need to be informed'. This remains, for me, a crucial factor, and often, sufficient justification. But the films I think we need most, need to do more. They need to combine honest reportage, accurate information, empathetic testimony and counter-narratives in order to break the hold of the received opinions, conventional wisdoms and varieties of misinformation of the corporate media. They should avoid sentimentality and challenge propaganda. They need to address the viewer's intelligence, and invite them to feel included. They don't need to offer simplistic solutions which fall short of the global scale of political reality. They need to analyze and to deal with ideas, to encourage people to think at the same time that they feel, and feel at the same time they think. A sense of humor, a little satire, and a dose of irony would not come amiss. As Kleinhans (2018) put it, films that help us 'imagine that change is needed, that it is possible, and what it might look like' (2018). There are no formulae for doing any of this, because the application of a formula is already to risk undermining a film's political efficacy, which lies not in declaring a pre-established political argument but eliciting one, coaxing the viewer to stake out their own position.

Perhaps the odds are against succeeding. The intention to produce a counter-narrative to mainstream ideology can hardly be carried out except outside the mainstream media, where do-it-yourself cultural production is pitted like David against the Goliath of the globalized cultural monopolies. But then even going viral will hardly slay the monster, on which in any case we depend, for who else provides the infrastructure and the means for our interventions? The internet, to be sure, is a contradictory space, but it only reproduces the contradictions of the political economy that succoured it: the cloud is a euphemism which 
disguises the real ecological cost of the physical server farms where data resides, and which consume ever increasing amounts of electricity. This is the material reality.

There are no certainties. I am left with a feeling of frustration, the vexation of the political filmmaker struggling for their film to find the wider audience that it's made for - but also a great sense of urgency. 


\section{REFERENCES}

Benjamin, Walter. 1999. 'Left-Wing Melancholy' in Selected Writings, Vol.2. Belknap Press of Harvard University Press.

Benjamin, Walter. 1969. 'Theses on the Philosophy of History' in Hannah Arendt, ed., Illuminations, New York: Schocken Books.

Braverman, Harry. 1974. Labour and Monopoly Capital. Monthly Review Press.

Brecht, B. 2000. 'The Radio as a Communications Apparatus', in M. Silberman (ed.), Brecht on Film and Radio. London: Methuen.

Brown, William. 2018. 'The Lure of Becoming Cinema' in Ewa Mazierska and Lars Kristensen, eds., Contemporary Cinema and Neoliberal Ideology. Abingdon: Routledge.

Buck-Morss, Susan. 1991. The Dialectics of Seeing, Cambridge, Mass.: MIT Press

Chanan, Michael, ed. 1976. Chilean Cinema. London: BFI.

Chanan, Michael, ed. 1983. Twenty-five Years of the New Latin American Cinema. London: BFI and Channel Four Television.

Chanan, Michael. 1997. 'The Changing Geography of Third Cinema', Screen, Vol.38, no.4. Chanan, Michael. 2007. The Politics of Documentary. London: BFI.

Chanan, Michael. 2015. 'Swallowing Time: On the immaterial Labour of the Video Blogger' in Ewa Mazierska and Lars Kristensen, eds., Marxism and Film Activism: Screening Alternative Worlds. New York: Berghan Books.

Chanan, Michael and Lee Salter. 2016. 'Secret City, A Reception Diary', in Routledge Companion to Cinema and Politics, eds, Yannis Tzioumakis and Claire Molloy, London: Routledge.

Chanan, Michael. 2018. 'How to make a film about money and debt without any money and without falling into debt' in Constantin Parvulesco, ed., Global Finance on Screen, London: Routledge.

Clooney, George. 2017. 'George Clooney: Trump is a "Hollywood elitist”, Bannon is a "failed director"”, www.theguardian.com/film/2017/feb/22/george-clooney-donaldtrump-steve-bannon-hollywood-elite

Dobb, Maurice. 1963. Studies in the Development of Capitalism. London: Routledge.

Freud, Sigmund. 1917. 'Mourning and Melancholia', Complete Works Vol.XIV, London: Hogarth Press.

García Espinosa, Julio. 1983. 'For an Imperfect Cinema', in Michael Chanan, ed., Twentyfive Years of the New Latin American Cinema. London: BFI and Channel Four.

Goldfarb, Brian. 2000. 'Local Television and Community Politics in Brazil' in Chon Noriega, ed., Visible Nations, Latin American Cinema and Video. Minneapolis: 
University of Minnesota Press.

Hardt, M. and A.Negri. 2000. Empire. Cambridge, MA: Harvard University Press.

Jameson, Fredric. 2003. 'The Future of the City'. New Left Review 21, second series.

Lanchester, John. 2017. 'You Are the Product', LRB Vol.39 No.16.

Lazzarato, M. 1996. 'Immaterial Labour', in P. Virno and M. Hardt (eds.), Radical Thought in Italy. Minnesota: University of Minnesota Press.

Liñero Arend, Germán. 2010. Apuntes para una historia del video en Chile. Santiago: Ocho Libros.

MacDougall, David. 2001. 'Renewing ethnographic film', in Anthropology Today, Vol 17 No 3.

Mattelart, Armand and Mattelart, Michèle. 1979. De L'Usage des Media en temps de crise. Paris: Editions Alain Moreau.

Nichols, Bill. 2001. Introduction to Documentary. Bloomington, IN: Indiana University Press.

Rotha, Paul. 1973. Documentary Diary. London: Secker \& Warburg.

Schiwy, Freya. Indianising Film, Decolonisation, the Andes, \& the Question of Technology. New Brunswick: Rutgers University Press, 2009.

Solanas, Fernando et.al. 1978. 'Cinéma d'auteur ou cinéma d'intervention?'. Paris: CinémAction I.

Solanas, Fernando and G etino, Octavio Getino. 1983. 'Towards a Third Cinema', in Michael Chanan ed., Twenty-five Years of the New Latin American Cinema. London: BFI/ Channel 4.

Traverso, Enzo. 2016. Left-Wing Melancholia, Marxism, History and Memory. New York: Columbia University Press.

Wren, Adam. 2016. 'What I Learned Binge-Watching Steve Bannon's Documentaries', Politico, www.politico.com/magazine/story/2016/12/steve-bannon-films-moviesdocumentaries- trump-hollywood-214495

Youssef, Nancy. 2005. 'A Critical Look at Detroit: 2 filmmakers team up to scrutinize the city block by block'. Detroit Free Press, 16 March 2005.

1 The episode can be seen in the chapter 'Defending Libraries' in Chronicle of Protest. 